\title{
Presence of a soluble inhibitor of thyroid iodination in primary cultures of thyroid cells
}

Laura B Bocanera ${ }^{1}$, Paula Aphalo, Mario A Pisarev ${ }^{1,2}$, Roland Gärtner ${ }^{3}$, Daniel Silberschmidt ${ }^{2}$, Guillermo J Juvenal $^{1,2}$, Gabriela Beraldi ${ }^{2}$ and Leon Krawiec ${ }^{2}$

Nuclear Biochemistry Division, Department of Radiobiology, Argentine Atomic Energy Commission and Department of Human Biochemistry, University of Buenos Aires School of Medicine, Buenos Aires, Argentina, ${ }^{1}$ Argentine Atomic Energy Commission (CNEA), ${ }^{2}$ Argentine National Research Council (CONICET) and ${ }^{3}$ Medizinische Klinik, Klinikum Innenstadt, Ludwig Maximilians Universität München, München, Germany

(Correspondence should be addressed to L Krawiec, Division Bioquimica Nuclear, Depto. de Radiobiología, Comisión Nacional de Energía Atómica, Av. del Libertador 8250, 1429 Buenos Aires, Argentina; Email: krawiec@cnea.gov.ar)

\begin{abstract}
Monolayer cultures of thyroid cells lose their iodide organification capacity a few days before the disappearance of thyroid peroxidase (TPO) activity. The present studies were performed in order to clarify this point. The above mentioned difference was due to the presence of an inhibitor in the monolayer thyroid cells culture, given that total homogenate prepared from confluent cells caused a significant inhibition of activity of TPO from fresh tissue. The inhibitor was localized in the $105000 \mathrm{~g}$ supernatant of the homogenate of the cell culture, but not in a similar preparation obtained from fresh thyroid. It is thermostable, dialyzable and has a molecular weight of less than $2 \mathrm{kDa}$. Addition of the inhibitor at the end of the reaction of tyrosine iodination failed to alter the results. This fact suggests that the compound does not destroy the iodinated product. The presence of the cytosolic inhibitor was observed in monolayer thyroid cell cultures of different species (bovine, porcine, rat and human) but not in free follicles cultures.
\end{abstract}

European Journal of Endocrinology 141 55-60

\section{Introduction}

Thyroid hormone synthesis results from two successive reactions catalyzed by thyroid peroxidase (TPO) in the presence of $\mathrm{H}_{2} \mathrm{O}_{2}$ : (i) the iodination of several tyrosyl residues in a matrix, thyroglobulin, and (ii) the condensation of some iodotyrosyl residues to form iodotyronines. During the last decades thyroid cell cultures have been utilized as a model for the analysis of gland function and its regulation. However, it was noticed that monolayer primary cell cultures of pig $(1-3)$ and dog $(4,5)$ thyroid show a time-course decline of iodide organification and TPO activity. To date, unequivocal data on this issue are not available. The present studies were performed to contribute to the understanding of this point and provide evidence of the presence of a soluble inhibitor of iodide organification.

\section{Materials and methods}

\section{Cell culture}

Bovine thyroids were obtained at a local slaughterhouse immediately after slaughter and transported to the laboratory in ice-cold saline containing $100 \mathrm{U} / \mathrm{ml}$ penicillin and $100 \mu \mathrm{g} / \mathrm{ml}$ streptomycin. The glands were carefully dissected, cut into small pieces under sterile conditions and digested with $1 \mathrm{mg} / \mathrm{ml}$ collagenase type $1 \mathrm{~A}$ and DNAse $20 \mu \mathrm{g} / \mathrm{ml}$ in medium 199 with $2.2 \mathrm{mg} / \mathrm{ml} \mathrm{NaCO}{ }_{3} \mathrm{H}, 5 \mu \mathrm{g} / \mathrm{ml}$ transferrin, $5 \mu \mathrm{g} / \mathrm{ml}$ insulin, $2.5 \mu \mathrm{g} / \mathrm{ml}$ amphotericin $\mathrm{B}, 100 \mathrm{U} / \mathrm{ml}$ penicillin and $100 \mu \mathrm{g} / \mathrm{ml}$ streptomycin, in a relation of $10 \mathrm{ml} / \mathrm{g}$ tissue, at $39^{\circ} \mathrm{C}$ for $90 \mathrm{~min}$. The digested material was filtered through sterile gauze and centrifuged at 2000 r.p.m. for $30 \mathrm{~s}$, washed twice with the medium and resuspended in the complete M-199 medium containing 5\% fetal calf serum (FCS). The follicles were seeded in standard plates for monolayer cultures or in dishes supplied with a hydrophobic layer to keep the follicles in suspension. After $48 \mathrm{~h}$ the medium was replaced by another containing $0.1 \%$ FCS. The cultures were stopped at different days and assays were performed as indicated below.

Human thyroids were obtained from patients who underwent surgery, and were transported to the laboratory in iced saline. The culture method was similar to that described above except that the medium was Dulbecco's modified MEM. 
Intact porcine thyroid follicles were isolated from glands obtained immediately after death. An artery of the gland was dissected free from surrounding tissue and injected with about $8 \mathrm{ml}$ collagenase solution $(1.3 \mathrm{mg} / \mathrm{ml}$ in Hepes-buffered medium 199). After incubation for $45 \mathrm{~min}$ at $37^{\circ} \mathrm{C}$ in medium 199 , the thyroid capsule could be disrupted and intact follicles could be liberated by gently shaking the digested tissue in culture medium. Several washing and sedimentation steps removed disrupted follicles and single cells. Follicles were incubated for $24 \mathrm{~h}$ in a humidified atmosphere with $5 \%$ carbon dioxide at $37^{\circ} \mathrm{C}$ in sodium hydrogencarbonate-buffered medium 199 supplemented with glucose $(2 \mathrm{~g} / \mathrm{l})$, glutamine $(200 \mathrm{mmol} / \mathrm{l})$, penicillin $(100 \mathrm{U} / \mathrm{ml})$, streptomycin $(100 \mu \mathrm{g} / \mathrm{ml})$, amphotericin B $(1 \mu \mathrm{g} / \mathrm{ml})$, gentamicin $(50 \mu \mathrm{g} / \mathrm{ml})$, transferrin $(5 \mu \mathrm{g} / \mathrm{ml})$ and insulin $(10 \mathrm{ng} / \mathrm{ml})$ as standard culture medium, which was further enriched with trypsin inhibitor $(100 \mu \mathrm{g} / \mathrm{ml})$, potassium iodide $(10 \mathrm{nmol} / \mathrm{l})$ for normalization of iodine content, 1\% FCS and 1\% Biotectmedium for this resting and repair phase. Culture dishes supplied with a hydrophobic membrane were used to keep the follicles in suspension and to prevent any fibroblast growth. For the monolayer cell cultures the follicles were seeded in standard culture dishes.

FRTL-5 cells (ATTC \#8305) were kindly provided by Dr LD Kohn (NIH, Bethesda, MD, USA) and Interthyr Research Foundation (Baltimore, MD, USA). Cells were grown in Coon's modified F-12 medium supplemented with $5 \%$ calf serum, $10 \mu \mathrm{g} / \mathrm{ml}$ insulin, $5 \mu \mathrm{g} / \mathrm{ml}$ transferrin, $10 \mathrm{ng} / \mathrm{ml}$ glycyl-L-histidyl-L-lysine acetate (GHL), $10 \mathrm{ng} / \mathrm{ml}$ somatostatin, $10 \mathrm{nmol} / \mathrm{l}$ cortisol, $1 \mathrm{mU} / \mathrm{ml}$ thyrotropin, $100 \mathrm{U} / \mathrm{ml}$ penicillin and $100 \mu \mathrm{g} / \mathrm{ml}$ streptomycin.

Cultures were performed in $100 \mathrm{~mm}$ diameter plates at $37^{\circ} \mathrm{C}$ under an atmosphere of $95 \%$ air and $5 \% \mathrm{CO}_{2}$ in an humidified incubator. Medium was replaced every 3 days.

\section{Iodide organification}

The cells, maintained in $35 \mathrm{~mm}$ diameter plates, were washed three times with Dulbecco's modified MEM and incubated at $37^{\circ} \mathrm{C}$ for $2 \mathrm{~h}$ with the same medium containing $1 \mu \mathrm{mol} / \mathrm{l} \mathrm{KI}$ and $1 \mu \mathrm{Ci} / \mathrm{ml} \mathrm{Na}^{125} \mathrm{I}$. At the end of the incubation the cells were washed twice with cold PBS, and detached from the wells by addition of PBS $2 \mathrm{mmol} / \mathrm{l}$ EDTA. Total and TCA-precipitable radioactivity were then determined in an automatic gamma counter and referred to the protein content of each well.

\section{Isolation of TPO}

Fresh glands were dissected, cut into small pieces and homogenized in $0.1 \mathrm{~mol} / \mathrm{l}$ phosphate buffer, $0.1 \mathrm{mmol} / \mathrm{l}$ $\mathrm{KI} \mathrm{pH} 8.0(1 / 5 ; \mathrm{w} / \mathrm{v})$. The homogenate was filtered through gauze and centrifuged at $900 \mathrm{~g}$ for $10 \mathrm{~min}$ at $4{ }^{\circ} \mathrm{C}$. The resulting supernatant was centrifuged at $105000 \mathrm{~g}$ for $60 \mathrm{~min}$. The pellet was resuspended $(1 / 1$, $\mathrm{w} / \mathrm{v}$ ) in the same buffer containing $0.6 \%$ Triton $\mathrm{X}-100$ and kept on ice, with frequent agitation, for $180 \mathrm{~min}$. After centrifugation at $105000 \mathrm{~g}$ for $60 \mathrm{~min}$ the resulting supernatant was utilized as the source of solubilized TPO.

When TPO was isolated from cells in culture a similar procedure was applied. Confluent cells grown in $10 \mathrm{~cm}$ diameter plates were homogenized in $1 \mathrm{ml}$ phosphate buffer, $0.1 \mathrm{mmol} / \mathrm{l} \mathrm{KI} \mathrm{pH} \mathrm{8.0.} \mathrm{The} \mathrm{homogenate} \mathrm{was}$ centrifuged at $105000 \mathrm{~g}$ for $60 \mathrm{~min}$ and the pellet was processed as the fresh tissue pellet.

\section{Isolation of cell supernatant}

The first $105000 \mathrm{~g}$ supernatant obtained from monolayer cells cultures, free follicles and fresh tissue homogenates was analyzed for its inhibitory activity on TPO extracted from fresh glands.

\section{TPO activity assay}

TPO activity was determined following three different methods.

(a) Tyrosine iodination assay The method described by DeGroot and Davis (6) was followed. Each tube contained $500 \mu \mathrm{g}$ protein of the enzyme preparation, $1 \mathrm{mmol} / \mathrm{l}$ tyrosine, $0.01 \mathrm{mmol} / \mathrm{l} \mathrm{KI}, 0.5 \mathrm{mg}$ glucose oxidase, $1 \mathrm{mmol} / \mathrm{l}$ glucose and $0.1 \mu \mathrm{Ci} \mathrm{Na}^{125} \mathrm{I}$, phosphate buffer $0.1 \mathrm{~mol} / \mathrm{l} \mathrm{pH} 7.0 \mathrm{in}$ a total volume of $1 \mathrm{ml}$. The reaction was started by the addition of glucose oxidase, and the tubes were kept at $37^{\circ} \mathrm{C}$ for $20 \mathrm{~min}$. At the end of the incubation, two drops each of concentrated $\mathrm{HCl}$ and of $25 \%$ sodium thiosulfate were added. One milliliter buffer containing $800 \mathrm{mg}$ Dowex 50WX8-40 resin was then added and shaken for $10 \mathrm{~min}$ at $37^{\circ} \mathrm{C}$. The resin was washed 5 times with water and the radioactivity bound to the resin was measured in an automatic gamma counter. This method was used in every case unless otherwise indicated.

(b) Tri-iodide assay The method of Nagataki et al. (7) was used to determine the amount of tri-iodide formed. The increase in optical density (OD) at either 287 or $353 \mathrm{~nm}$, during $3 \mathrm{~min}$, was measured in a spectrophotometer cuvette containing the enzyme $(20 \mu \mathrm{l}$, equivalent to approximately $500 \mu \mathrm{g}$ protein), $0.5 \mathrm{ml}$ $0.08 \mathrm{~mol} / \mathrm{l}$ iodide in $0.1 \mathrm{~mol} / \mathrm{l}$ phosphate buffer $\mathrm{pH} 7.0$, in a final volume of $3 \mathrm{ml}$. The reaction was started by the addition of $20 \mu \mathrm{l} 0.08 \mathrm{~mol} / \mathrm{l} \mathrm{H}_{2} \mathrm{O}_{2}$.

(c) Guaiacol assay This assay was performed following the method described by Nagataki et al. (7). Briefly, the spectrophotometer cuvette contained $0.5 \mathrm{ml} 0.08 \mathrm{~mol} / \mathrm{l}$ guaiacol, $2 \mathrm{ml}$ phosphate buffer $0.1 \mathrm{~mol} / \mathrm{l}, \mathrm{pH} 7.0$, and the solubilized enzyme in a final volume of $3 \mathrm{ml}$. The reaction was started by the addition of $20 \mu \mathrm{l} 0.08 \mathrm{~mol} / \mathrm{l}$ 
Figure 1 TPO activity in cells cultured for up to 14 days. The enzymatic activity was determined by tyrosine iodination in samples from bovine cells harvested after 3, 5, 7,11 and 14 days of culture. Under the same conditions the ${ }^{125}$ I organification (as a percentage of total radioactivity present in each well) was determined and related to total protein content. Each value is the average \pm S.E.M. of 8 samples from 3 different experiments. $P<0.01$ when compared with the ' 0 ' time controls.

$\mathrm{H}_{2} \mathrm{O}_{2}$ and followed by the variation in $\mathrm{OD}$ at $470 \mathrm{~nm}$ during $3 \mathrm{~min}$.

\section{Dialysis}

The $105000 \mathrm{~g}$ supernatant $(2 \mathrm{ml})$ was dialyzed for 3 days at $4{ }^{\circ} \mathrm{C}$, against 3 liters $0.1 \mathrm{~mol} / \mathrm{l}$ phosphate buffer, $\mathrm{pH}$ 8.0.

Protein was determined according to Lowry et al. (8). All reagents were obtained from Sigma Chemical Co. (St Louis, MO, USA) and the $\mathrm{Na}^{125}$ I was purchased from New England Nuclear. Each experiment was repeated at least 4 times and each point was run in quadruplicate. Statistical significance of the differences among groups was calculated according to Dunnet (9).

\section{Results}

The monolayer cell culture of bovine thyroid, at confluence, shows neither organification nor TPO activity. Studying the correlation between these two parameters at different days of culture, it was possible to verify that the enzymatic activity decreased steadily during the observation period, from 0 to 14 days of culture. Conversely, the organification practically disappeared on the 7 th day (Fig. 1).

In order to explain the disagreement between organification and TPO levels and anticipating the existence of an inhibitor, we studied the action of monolayer cell extracts on fresh tissue TPO activity. As seen in Fig. 2 the addition of total homogenate of monolayer cells cultured until confluence caused a significant inhibition of the fresh tissue TPO activity, measured by the tyrosine iodination assay. When the

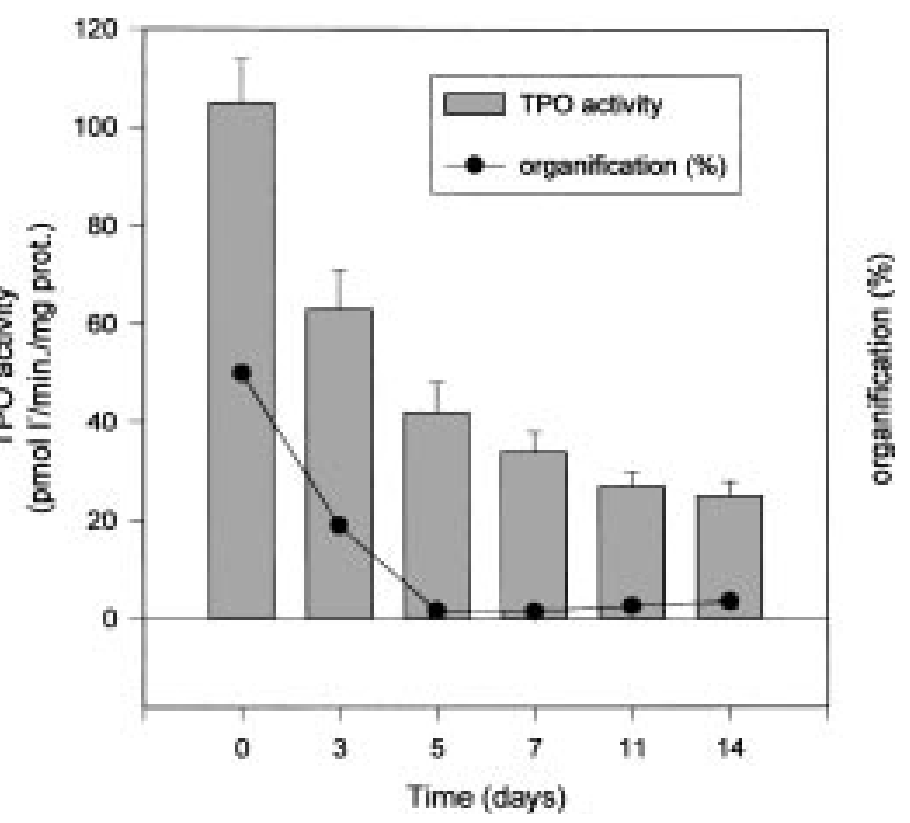

subcellular localization of the inhibitory activity was analyzed, the $105000 \mathrm{~g}$ supernatant from bovine thyroid cells cultured until confluence doubled the percentage of inhibition of the enzymatic activity caused by the total homogenate. Neither the $105000 \mathrm{~g}$

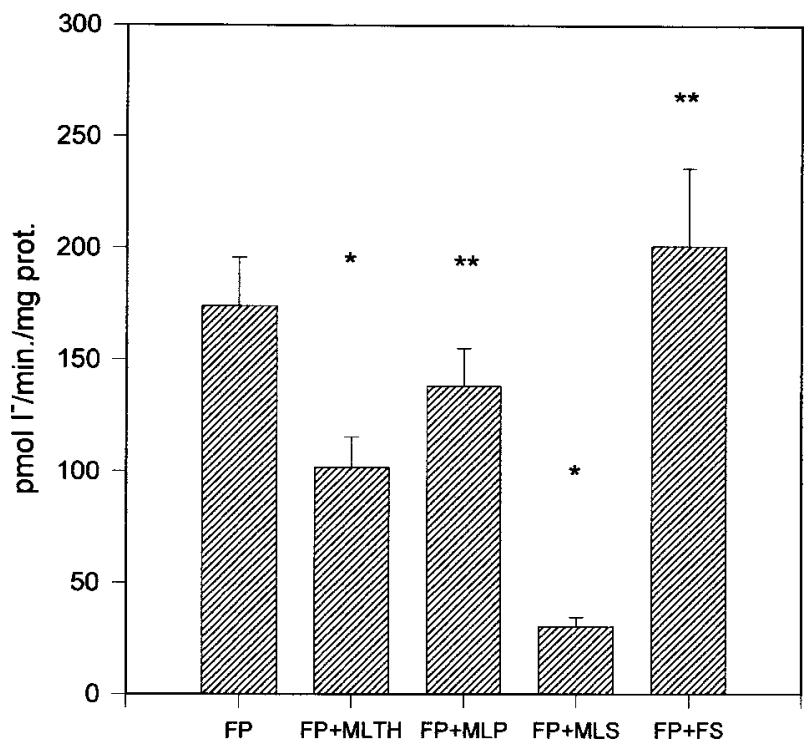

Figure 2 Tyrosine iodinase activity, as an index of TPO activity, was measured in a fresh preparation (FP) of the solubilized enzyme and after the addition of bovine monolayer cell culture total homogenate (MLTH), monolayer cell culture pellet (MLP), monolayer cell culture supernatant (MLS) or fresh (non cultured) supernatant (FS). Each value is the average \pm S.E.M. of 3 different experiments $(n=9$ samples). ${ }^{\star} P<0.01$ and ${ }^{* *}$ not significant compared with the control (fresh pellet) according to Dunnet's test. 
Table 1 Inhibitory effect of the bovine monolayer cell culture supernatant (MLS) on the fresh pellet (FP) TPO activity determined by three different methods. Each value is the average \pm S.E.M. of 6-12 samples from 2-3 different experiments.

\begin{tabular}{lcc}
\hline Assay & FP & FP + MLS \\
\hline Tyrosine iodination (pmol I- $/ \mathrm{min} / \mathrm{mg}$ prot.) & $174.0 \pm 21.8$ & $30.3 \pm 4.0^{*}$ \\
Tri-iodide formation (nmol I- $/ \mathrm{min} / / \mathrm{mg}$ prot.) & $146.7 \pm 2.3$ & $63.0 \pm 2.8^{*}$ \\
Guaiacol oxidation (OD $470 \mathrm{~nm} / \mathrm{min} / \mathrm{mg}$ prot.) & $0.205 \pm 0.023$ & $0.237 \pm 0.019$ \\
\hline${ }^{*} P<0.01$ compared with the samples incubated without the supernatant. \\
FP, TPO extracted from fresh pellet; MLS, supernatant obtained from confluent monolayer bovine \\
thyroid cells.
\end{tabular}

resuspended pellet from those cells, nor the $105000 \mathrm{~g}$ supernatant prepared from fresh tissue caused a significant change in this parameter (Fig. 2).

The decrease in TPO activity of fresh thyroid, caused by the $105000 \mathrm{~g}$ supernatant of calf cells cultured until confluence, was evident when the enzymatic activity was determined either by the tyrosine iodination or the tri-iodide assays, but not when the guaiacol assay was used (Table 1).

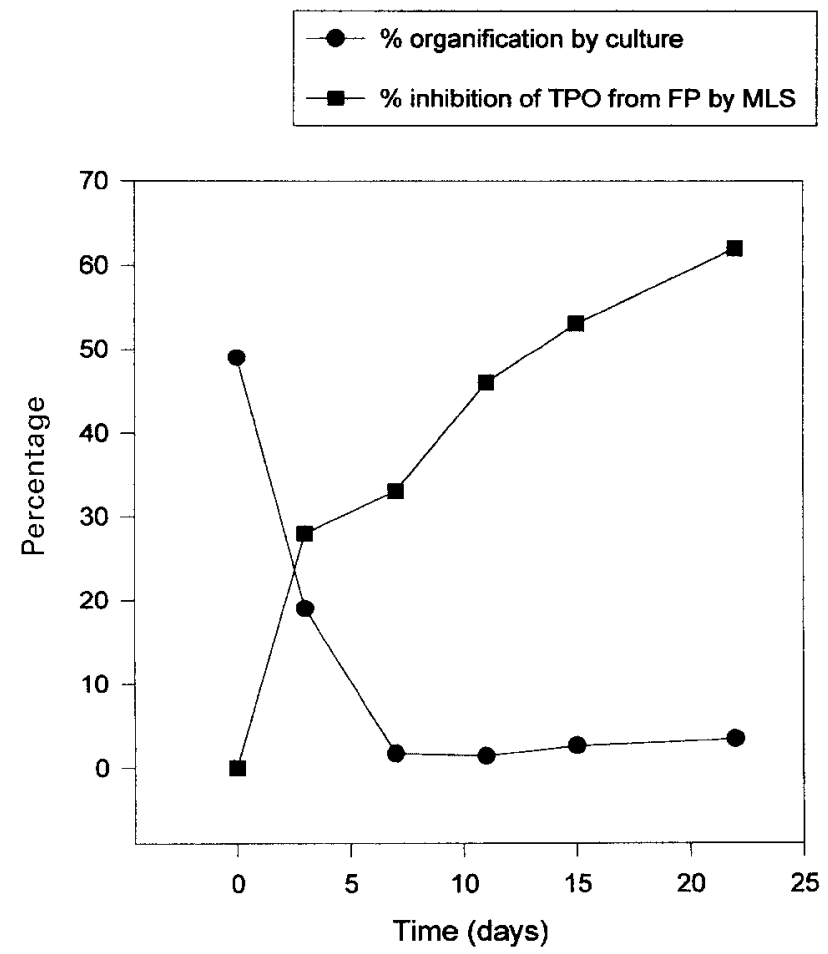

Figure 3 Bovine thyroid cells were cultured for the indicated days. The ${ }^{125} \mathrm{I}$ organification (as a percentage of total radioactivity present in each well; $(\bullet)$ ) was determined in quadruplicate and related to total protein content. Under the same conditions the capability of the monolayer cell culture supernatant (MLS) to inhibit the tyrosine iodinating activity of a fresh pellet (FP) TPO preparation was determined $(\boldsymbol{\square})$. Each value is the average of 12 samples from 3 different experiments.
Figure 3 depicts the iodide organification and inhibitor levels in monolayers culture during the same period: a sustained increase in the inhibitory effect of cytosol extract on TPO activity coincides with the disappearance of the organification function. Otherwise, in free follicle cultures when the organification had disappeared $\left(9^{\text {th }}\right.$ day), the inhibitor was absent (data not shown).

Confirming these results, the free follicles organification was impaired by the addition of monolayer cell cultures supernatant (Table 2), demonstrating that the cytosolic inhibitor penetrates the cell membrane.

The thermal sensitivity of the inhibitory factor was studied. Boiling of the bovine cell supernatant for 1-15 min failed to alter the inhibitory activity. (Fig. 4).

When the $105000 \mathrm{~g}$ supernatant was extensively dialyzed, the inhibitory action on TPO activity disappeared and was totally recovered in the dialysis liquid. Taking into account the pore size of the dialysis tubing it can be assumed that the molecular weight of the inhibitor is less than $2 \mathrm{kDa}$. The properties of the inhibitor were not altered by the dialysis conditions (Table 3 ).

To determine the existence of the inhibitor in thyroids from different species, the activity of supernatants obtained from monolayer primary cultures of bovine, porcine and human thyroid cells and from the rat thyroid cell line, FRTL-5, were compared. As shown in Table 4 , the inhibitory action was present in all the tested supernatants.

Table 2 Effect of monolayer cell culture supernatant on the organification level in free follicles.

\begin{tabular}{lc}
\hline Assay & \% of organification \\
\hline Bovine free follicles & 43 \\
Bovine free follicles + BMLS & 27 \\
Porcine free follicles & 51 \\
Porcine free follicles + PMLS & 9 \\
\hline
\end{tabular}

The organification assay was as described in Materials and methods, except that Dulbecco's modified MEM was replaced by Krebs Ringer Hepes buffer pH 7.4. Free follicles were preincubated for $15 \mathrm{~min}$ in the presence of supernatant. BMLS, bovine monolayer cell culture supernatant; PMLS, porcine monolayer cell culture supernatant. 


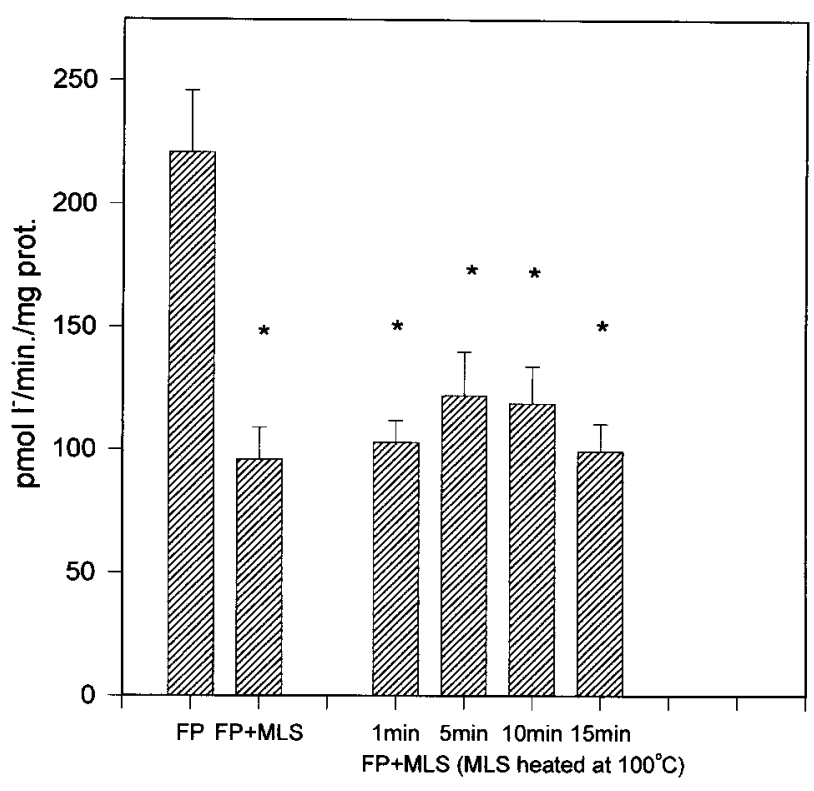

Figure 4 Effect of heating on the inhibitory activity of the monolaye cell culture supernatant (MLS). The MLS was boiled for 1-15 min and its inhibitory effect on the tyrosine iodinating activity of TPO extracted from the fresh pellet (FP) was determined. Each value is the average \pm S.E.M. of 9 samples from 3 different experiments. ${ }^{\star} P<0.01$ compared with fresh pellet alone (control).

The presence of the inhibitor was evaluated in supernatants obtained from cells cultured as monolayers or as free follicles. The results indicate that it appears only when the cells are attached to the culture dish (Table 5).

\section{Discussion}

Early observations have shown an impairment in the iodination activity $(1-5)$ of thyroid cells cultured as monolayers. A decrease in TPO transcription and/or translation, as shown by Chazenbalk et al. (10) in the early phase of primary culture of dog thyroid cells, was proposed as a possible explanation for this fact. Nevertheless, our observation that the reduction in the organification level in bovine primary culture, with

Table 3 Effect of dialysis on the bovine TPO inhibitor.

\begin{tabular}{lc}
\hline Assay & $\begin{array}{c}\text { TPO activity } \\
\text { (pmol I } / \text { min/mg prot.) }\end{array}$ \\
\hline Fresh bovine TPO & 335.0 \\
Fresh bovine TPO + MLS & 95.9 \\
Fresh bovine TPO + MLSR & 99.1 \\
Fresh bovine TPO + MLSD & 324.9 \\
\hline
\end{tabular}

Bovine monolayer cell culture supernatant was dialyzed for $72 \mathrm{~h}$, as indicated in Materials and methods. MLS, bovine monolayer cell culture supernatant; MLSR, bovine monolayer cell culture supernatant refrigerated for $72 \mathrm{~h}$; MLSD, dialyzed bovine monolayer cell culture supernatant.
Table 4 Effect of supernatant from different species. Comparison of the inhibitory effect of the supernatants obtained from primary monolayer cell culture of bovine (BMLS), human (HMLS), porcine (PMLS) cells or from FRTL-5 cells (FRTL-5 S) on the tyrosine iodinating activity of fresh thyroid peroxidase (TPO) from bovine and porcine thyroid. Each value is the average \pm S.E.M. of 8-9 samples from 3 different experiments.

TPO activity

Assay

(pmol I- $/ \mathrm{min} / \mathrm{mg}$ prot.)

Fresh bovine TPO $260 \pm 30$

Fresh bovine TPO + BMLS

Fresh bovine TPO + FRTL-5 S

Fresh bovine TPO + HMLS

Fresh porcine TPO

$37 \pm 5^{*}$

$72 \pm 6^{*}$

$124 \pm 11^{*}$

$425 \pm 34$

Fresh porcine TPO + PMLS

$240 \pm 23^{*}$

${ }^{*} P<0.01$ compared with fresh TPO (control).

time, is greater than the fall in TPO activity, suggests that additional mechanisms may also participate. The appearance of the inhibitory factor would explain this difference (Fig. 1).

Subcellular distribution studies demonstrate that this compound is present in the soluble fraction obtained from thyroid monolayer cell cultures, but not in the same fraction prepared from fresh tissue. Moreover, bovine and porcine free follicles do not show the presence of the inhibitor, suggesting that the cellular attachment to the dishes is important for the presence of the inhibitory action. This was confirmed by the results obtained with porcine and rat monolayer cultures. The cell supernatant from the FRTL-5 cell line had a significant inhibitory action. In this regard it is important to point out that this cell line has very poor thyroid hormone synthesis (11).

The fact that the inhibitory action is absent in the free follicles supernatant precludes the possibility that phenol red could be the inhibitor, as was postulated by Gruffat et al. (12), because either monolayer thyroid

Table 5 Influence of the cell culture system on the presence of the inhibitor. Comparison of the inhibitory effect of the supernatants obtained either from primary monolayer cell culture (MLS) or from free follicles culture (FFS) from bovine and porcine $(P)$ thyroid on the fresh tissue TPO activity. In every case $100 \mu \mathrm{g}$ supernatant protein were used. Each value is the average \pm S.E.M. of 5-6 samples from 2 different experiments.

\begin{tabular}{lc}
\hline Assay & $\begin{array}{c}\text { TPO activity } \\
\text { (pmol I- } / \mathrm{min} / \mathrm{mg} \text { prot.) }\end{array}$ \\
\hline Bovine TPO & $337 \pm 38$ \\
Bovine TPO + MLS & $76 \pm 13^{*}$ \\
Bovine TPO + FFS & $318 \pm 66$ \\
Porcine TPO & $417 \pm 45$ \\
Porcine TPO + PMLS & $100 \pm 12^{*}$ \\
Porcine TPO + PFFS & $401 \pm 42$
\end{tabular}

${ }^{*} P<0.01$ versus fresh TPO (control). 
cells or free follicles were cultured in the presence of phenol red.

In order to characterize this compound further, several studies were performed. The inhibition of iodination was detected when TPO activity was determined by the tyrosine iodinase and tri-iodide methods, but not by the guaiacol technique. These results would suggest that the effect takes place on the interaction between the enzyme and the iodide, and that the inhibitory compound decreases iodide utilization.

The possibility that the inhibitor might affect the iodotyrosine formed (e.g. acting as a dehalogenase) was also explored. The presence of dinitrotyrosine, an inhibitor of iodotyrosine dehalogenase (13), failed to alter our results. Also, the addition of the inhibitor after tyrosine iodination took place did not decrease the product of the TPO reaction (data not shown). Therefore, we conclude that the inhibitor does not have iodotyrosine dehalogenating activity.

Since thyroglobulin is one of the main components of the $105000 \mathrm{~g}$ supernatant, the possibility that it may be competing with the free tyrosine for the iodide was analyzed. When purified bovine thyroglobulin was added, in different amounts, to the reaction mixture of the tyrosine iodination assay, no inhibition was observed (data not shown).

Moreover, the finding that the soluble inhibitor is resistant to boiling argues against thyroglobulin and deiodinase being the putative compound. This property, in addition to the fact that the inhibitory effect disappears after dialysis, agree with the results obtained by Pommier et al. and Rosenthal et al. (14, 15), who postulated the existence of a dialyzable and thermostable factor in goiters with iodide organification defect.

It can be concluded that the iodide organification decrease observed in monolayer thyroid cell cultures is due to, at least, two events: (a) a decrease in TPO activity and (b) the existence of a thyroid peroxidase inhibitor which does not exist in free follicles, demonstrating the importance of the culture system used.

\section{Acknowledgements}

This work was supported by the following grants: PICT 0234 and 01868 from the National Agency for Scientific Promotion (SECYT), PIP 4601/96 from the Argentine National Research Council (CONICET), TM/ 46 from the University of Buenos Aires and the Argentine Atomic Energy Commission (CNEA).

\section{References}

1 Lissitzky S, Fayet G, Giraud A, Verrier B \& Torresani J. Thyrotropin-induced aggregation and reorganization into follicles of isolated porcine thyroid cells. I. Mechanism of action of thyrotropin and metabolic properties. European Journal of Biochemistry $19712488-99$.

2 Karlsson FA, Westermark K \& Westermark B. Functional properties of porcine thyroid follicles in suspension. Molecular and Cellular Endocrinology 198228 99-112.

3 Nishida M, Kumamoto T, Sano S, Yamaguchi T, Otsuka M \& Kawada J. Unusually high levels of thyroid hormones in isolated and/or monolayer cultured pig thyroid epithelial cells. Naturewissensch 199178 509-511.

4 Rapoport B, Adams RJ \& Rose M. Cultured thyroid cell adenosine $3^{\prime} 5^{\prime}$ cyclic monophosphate response to thyrotropin: loss and restoration of sensitivity to iodide inhibition. Endocrinology 1977 $100755-764$.

5 Roger PP \& Dumont JE. Thyrotrophin and the differential expression of proliferation and differentiation in dog thyroid cells in primary culture. Journal of Endocrinology $198396241-$ 249.

6 DeGroot LJ \& Davis AM. Studies on the biosynthesis of iodotyrosine: a soluble thyroidal iodide-peroxidase tyrosineiodinase system. Endocrinology 196270 492-504.

7 Nagataki S, Uchimura H, Masuyama Y \& Nakao K. Thyrotropin and thyroidal peroxidase activity Endocrinology 197392 363371.

8 Lowry OH, Rosebrough NJ, Farr AL \& Randall RJ. Protein measurement with the Folin phenol reagent. Journal of Biological Chemistry 1951193 265-275.

9 Dunnet CW. A multiple comparison procedure for comparing several treatments with a control. Journal of the American Statistical Association $1955501096-1121$.

10 Chazenbalk GD, Magnusson RP \& Rapoport B. Thyrotropin stimulation of cultured thyroid cells increases steady state levels of messenger ribonucleic acid for thyroid peroxidase. Molecular Endocrinology 1987 1 913-917.

11 Bidey SP. Comparative evaluation of FRTL- 5 against other cultured thyroid cell systems. In FRTL-5 Today, pp 13-16. Eds FS AmbesiImpiombato \& H Perrild. Amsterdam: Excerpta Medica, 1989.

12 Gruffat D, Gonzalvez S, Mauchamp J \& Chabaud O. Phenol red: an inhibitor of thyroglobulin iodination in cultured porcine thyroid cells. Molecular and Cellular Endocrinology 199181 195203.

13 Grimm MA \& Greer Y. Changes in thyroid secretion produced by inhibition of iodotyrosine deiodinase. Endocrinology $1968 \mathbf{8 3}$ 405-410.

14 Pommier J, Dominici R, Bougneres P, Rahmoun B \& Nunez J. A dialysable inhibitor bound to thyroglobulin from four simple goiters and from two goiters with iodine organification defect. Journal of Molecular Medicine 19772 169-177.

15 Rosenthal D, Carvalho-Guimaraes DP, Knobel M \& Medeiros-Neto GA. Dyshormonogenetic goiter: presence of an inhibitor of normal human thyroid peroxidase. Journal of Endocrinological Investigation $199013901-904$.

Received 23 December 1998

Accepted 9 April 1999 